\title{
Science enters desert debate
}

\section{United Nations considers creating advisory panel on land degradation akin to IPCC.}

\section{BY NATASHA GILBERT}

A desert may need no defining, but desertification is not so easy to pin down. Although the loss of soil nutrients and moisture threatens roughly a third of the world's land area, imperilling farming and biodiversity, scientists lack a clear definition of it or agreed standards to measure its causes and progression. That absence has hampered global efforts to tackle these problems under the United Nations Convention to Combat Desertification (UNCCD) - unable to track the impact of their funding, donors are reluctant to invest.

Next week, a meeting of UN member states in New York will begin to set out the steps needed to close that science gap and boost international efforts to tackle desertification. Possible actions include improving irrigation, increasing fertilization and promoting the use of land-management techniques that integrate forests with agriculture. The gathering will set the tone for a broader meeting, to be held on 10-21 October in Changwon, South Korea, of the 193 nations that are party to the UNCCD.

\section{SYMPTOMS AND CAUSES}

The UNCCD has had limited success since it came into force in 1996. "Donors must have a clear idea of how big the problem is and must be confident that we can measure progress in overcoming the problem," says William Dar, director-general of the International Crops Research Institute for the Semi-Arid Tropics in Andhra Pradesh, India.

Monitoring and assessment have so far focused mainly on the symptoms of land degradation and desertification, such as loss of top soil and decreased food production. But researchers need to understand how societal and economic factors, including poverty and child malnutrition, can drive these processes. They also need to learn how best to track desertification using satellite data. Remote

\section{LIVING ON DRY EARTH}

Roughly one-third of the world's population lives in dry-land areas, according to the most recent data from the UN's Millennium Ecosystem Assessment.

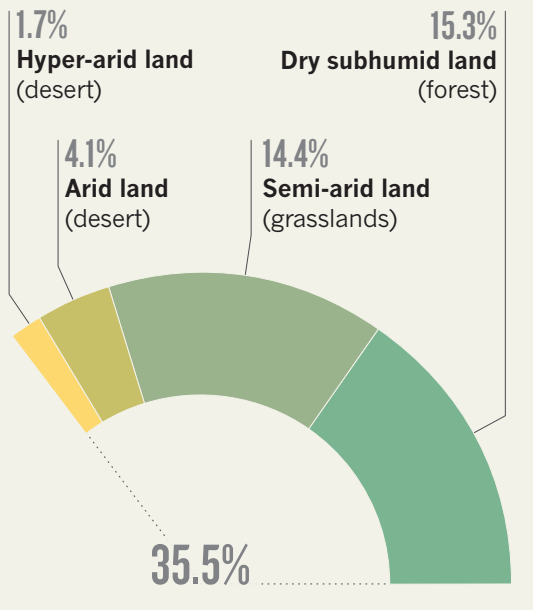

sensing can measure surface temperature and vegetation cover, for example, but those data can reflect temporary heat waves and dry spells rather than long-term desertification. As a first step, in 2012, nations that are party to the convention will provide data on two measurable indicators: the proportion of the population in vulnerable areas living above the poverty line and the area of land covered by vegetation. This will begin to provide a baseline from which to measure if and how land is degrading.

Governments of some developed nations also argue that land degradation is not a global issue of immediate concern to their citizens, but rather a problem limited to the dry lands of developing countries. Indeed, the convention applies only to lands that are already classed as 'dry', including arid and semi-arid regions, along with the dry subhumid (mainly forested) areas of Australia, China and Russia (see 'Living on dry earth').
The convention's secretariat now wants to broaden its scope to include humid and wet lands that are at risk of future degradation through the effects of climate change, for example. "Desertification can occur anywhere except in a desert," says Uriel Safriel, a desert ecologist at the Hebrew University of Jerusalem, Israel. This move could make the convention more directly relevant to rich nations.

"This is a turning point for the convention," says Mansour N'Diaye, acting deputy executive secretary to the convention. Next week's meeting is expected to propose the establishment of a scientific advisory panel on land and soil degradation, akin to the Intergovernmental Panel on Climate Change, which advises the convention's sister body on climate change. The panel would review the latest scientific data on the extent of land degradation, propose and assess efforts to combat it, and perhaps also develop specific targets for halting degradation, says Dar. But he notes that the panel's success would depend on ensuring that it was free from political interference and had the scientific independence needed to provide unbiased advice.

Safriel supports the secretariat's push for greater involvement of developed nations by highlighting the global nature of the problem. But he worries that developing countries may object, as it could draw attention away from desertification in their $\begin{array}{ll}\text { "It's stupid } & \text { own lands. Likewise, } \\ \text { to stick to dry } & \text { developed countries }\end{array}$ to stick to dry may be reluctant to comglobal issue." mit funds and resources, arguing that existing initiatives, such as the UN's

Millennium Development Goals to improve the lot of the world's poorest people, already address these issues. Despite these concerns, Safriel says, it is vital to broaden the convention's focus. "It's stupid to stick to dry lands, because not only dry lands will become dry. It's a global issue." -

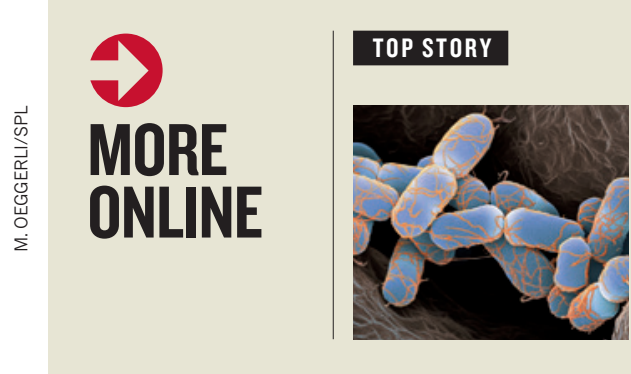

Germany learns from its latest E. coli outbreak go.nature.com/ gjppqe

\section{MORE NEWS}

- Seals slide towards extinction in Hawaiian reserve go.nature.com/s9mntl - Miniature microscopes capture neurons in action go.nature.com/zdblja - Detector suggests dark-matter particles may be lighter than expected go.nature.com/9uyptz

\section{SLIDESHOW}

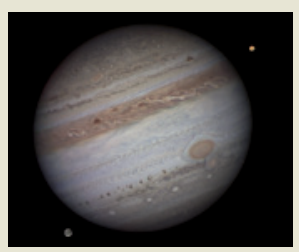

Jupiter shot takes prize for heavenly images go.nature. com/3khug4 